\title{
Research on the Teaching Design of Economic Mathematics Flipped Classroom Based on MOOC
}

\author{
Hong Wang \\ College of Finance \\ Qilu University of Technology \\ Jinan, China \\ jmjj55@126.com
}

\begin{abstract}
MOOCs and Flipped Class rooms have become hot topics around the world. They embody the essence of education informationization. Using MOOCs would be significant in economic mathematics teaching. For implementing the flipped classroom effectively based on MOOCs, it would study before class and learn in class with group discussion and collaborative by using MOOCs resources, and also would improve the ability after class, then the evaluate feedback would be given. All these could implement the effective flipped in classroom teaching, and then cultivate students' ability to learn and explore independently.
\end{abstract}

Keywords-MOOC; Flipped Classroom; economic mathematics; teaching research

\section{INTRODUCTION}

As an important foundation course in economic institutions, economic mathematics has a strong applicability. It can provide the necessary mathematical knowledge and mathematical methods for students in studying specialized courses, and also cultivate students' innovation ability and improve their mathematical application ability. However, in colleges and universities, the teaching mode of economic mathematics still adopts the traditional teaching method: Teachers teach knowledge in class for student's understanding students will finish the homework in time after class, and then teachers will make regular or irregular examinations for tutoring and answering questions after class. Curriculum reform is already undergoing heatedly, but it is too simple and boring on the teaching content, the organization way designed by the teacher, the teaching method and teaching idea of teacher inheritance. Teacher plays a main character in the organization way, so it is difficult to arouse students' enthusiasm for learning. Obviously it has lagged the requirement of the times development for the traditional teaching modes, so the integration of the information technology and math teaching will be one of the trends of math teaching development by modern teaching means and teaching philosophy. In the information technology background, how to create a teaching model, effective teaching methods and reasonable examination method which is suitable for creative talents training in economic mathematics courses, will becomes a hot issue in the modern reform of mathematics teaching.

\section{MOOCs Resources AND FLIPPED ClassRoOM}

Being a development mode online under the form of internet in teaching, MOOC is a massive open online course which been released by personal organization sharing and collaboration. It is promoted by the innovation of teaching philosophy and the deep application of cloud computing, internet and big data technology in education with openness and transparency unprecedentedly. It integrates modern information technology with education teaching by high quality teaching resource. It has promoted the reform and development of education teaching, and the essence of education information is embodied. The rapid development of MOOC is a challenge to the more closed education mode, and the massive open online course will be introduced gradually.

Flipped Classroom is originated in the United States. It means that teachers integrate the key points, difficulties and parts of new knowledge according to the teaching content, create instructional video related. Students learn new lesson by themselves with watching instructional video after class, and they will finish the test online by the instructional video, then they should have interaction and communication with their puzzle of the learning process in class. So students could understand and master the new knowledge, and then get teaching objectives. Flipped Classroom is flipped for the traditional teaching, the main way is that students study themselves before class, but teachers give tutoring in class, the roles of them were reversed, the arranging of teaching schedule and teaching process are flipped.

Its essence is affecting students' learning style and environment fundamentally by using modern education technology and teaching tools. Students will independent study before class by using multimedia courseware and video which is made by teachers. In class they will participate in teachers interactive activities (such as solve doubts, solve problems and explore) and finish the exercise. And then summarize and verify the teaching effect after class [1].

MOOC and flipped classrooms have become hot topics around the world, scholars have carried out a number of studies on these, more and more colleges and universities join the "MOOC" course to demonstrate the advantages of teaching resources fully [2]. And they try to use flipped classroom teaching mode, and achieve good results. 


\section{Research on Economic Mathematics FlipPed Classroom Teaching Based on MOOC}

\section{A. The significance of flipped classroom using MOOC in economic mathematics courses}

The learning process is to be accepted passively with planning, organizing and purposing to some degree, it needs teacher's guidance to require that students complete the objectives and requirements within the stipulated time. Teachers should pay attention to the development of students' abilities with different model when they choosing the model of teaching, and then choose the right way to improve their initiative and enthusiasm. So it accords with student requirements and needs of development to use blending learning based on the MOOCs video which is short and snappy.

The objectives of higher mathematics couldn't be separated from the teaching mode with deep reform based on MOOC. However, the teaching of economic mathematics cannot simply copy the MOOC; we should excavate the content of them and rich teaching content by using MOOC. We should integrate the relevant teaching ideas of flipped classroom into students' study, combine learning theory with teaching design, which is more conducive to promoting the reform of higher mathematics teaching and improving the quality of education teaching. In flipped classroom, it is particular emphasis on the teamwork between students in the class, teachers give guidance of targeted, it would achieve truly delaminated teaching and determine what the student needs. At the same time teachers should integrate the student' s self-study and learning online. Not only it will embody the teachers that play their major role in traditional courses, but also give expression to the student' $\mathrm{s}$ dominant role by learning online, and then it would realize the personalized learning, open up the student' s thinking space, and train their ability of learning and innovation. Take the opportunity of MOOCs, these would advance the reform of teaching and management, realize the deep integration of both, then solve the problem exposed in teaching of colleges and universities. Based on the significance, in the reform of teaching under MOOCs, how to carry out the flipped classroom effectively, integrate the information technology and mathematics teaching deeply.

\section{B. Research on economic mathematics flipped classroom teaching based on MOOC.}

MOOC is interactive with different from the Online open classes. Teachers could make the teaching resource as the link online. Student study the knowledge before class, explore and solve problems in class, these could improve the students' ability of inquiry and independent learning [3].

\section{1) Learning before class}

Choose the appropriate content for flipped classroom. Combine the student's characteristics and professional requirements, teachers should set clear learning goal, concentrate into a 5-10 minutes of micro-video, and inducts the students to learn online before class. MOOCs will offer many video resources for teachers to find the micro-video, which is consistent with their content and objectives of teaching as supplementary. Students could watch video before class, get learning resources of MOOCs by using wireless devices and wireless communication network anytime and anywhere, and communicate with others. Teachers should publish notification of learning tasks and offer answer questions online when students study online. When answered the question online, it would be focused on the student's common problems, and put them into the teaching content of offline courses. After the online courses, the teachers would announce the mainly content discussed offline courses to give reference and preparation for student [4]. Students would record their learning results and experiences, upload them to mobile internet for studying and discussing in class, thus students could become the subject truly in flipped classroom.

\section{2) The classroom teaching}

The communication in class is different from teaching mode online; it brings the different feelings to students. Students would feel better intimacy when they communicating face to face with teacher, it also consider the importance of emotional communication in teaching. Group discussions conducted to learning in class is better than solve the question online, these could inspire the ability of thinking and solving problems, make students feel involved stronger, and the learning effect is more pronounced.

To the common problems that exist, teachers summarize the problem of classroom study discussion; have a group discussion and collaborative learning. Using the statistical function of the test system, teachers will make the course content be targeted depending on the degree of acceptance of the students, including difficult to reassure, consolidation exercises, in-depth exploration and so on[5]. To the analyzation for the specific problem of teaching content, teachers should give the solutions and experience reflection. Teachers also should comment on the problems with students, summarize the learning content and explain the key difficulties in detail, so it could make help the students deepen their understanding, consolidation of knowledge points, and then enhance learning effect. Further grasp the students' thoughts and suggestions on the class mode should be given with questionnaire method, the teaching results also should be given feedback and be organized, and then make appropriate adjustments, so that it can get better teaching and delivery of knowledge [6].

\section{3) Ascension after class}

After class students could solve the problem left in class with the help of MOOC. For the knowledge, the intense training is implemented, teachers also set different level and angle on theme to inspire student.

It should be treated hierarchically to the specific questions for students. Teachers should make comments according to the students' completion, collect the exercises related to this section, set up a grading challenge operation according to the degree of difficulty, then students would challenge the task according to themselves ability to learn. These can not only stimulate their learning enthusiasm, but also consolidate the knowledge [7]. To the students finished better, give them the next stage of study instruction. To the else, understand and analyze their doubts and problems, find some special topics for coaching exercises to help them consolidate the foundation. 


\section{4) Evaluation and feedback}

It should be carried out check on the learner periodically to motivate the enthusiasm of studying. Provide different difficulty and deepness on checking contents based on different professional and level, and also evaluate comprehensively in terms of finishing the operation to get feedback useful. So it could provide a lot of helpful guidance for flipped classroom.

\section{SUMmary}

In the process of education information construction, the reform of the teaching mode of flipped classroom based on MOOCs, will be accomplished together through the multi-link, multi-level teaching practice activity. These have brought many challenges for the teachers and students. But it has very important application value in improving students' interest in economic mathematics, and cultivating students' mathematical application consciousness and mathematical literacy, then improve the teaching quality in school economics mathematics.

\section{REFERENCES}

[1] Liang Haifeng. "University mathematics is based on the exploration of "flipped classroom" teaching model”, Learning Weekly. 2016. (In Chinese)

[2] Li Wen, Huang Mingdong. "The opportunities and challenges comes from "MOOCs" to colleges and universities", China Higher Education. 2014. (In Chinese)

[3] Yang Yuemei, Chen Zhongmin, Pang Shuping. "The using of MOOCs in the teaching of advanced maths", Education Exploration. No.8,2015.(In Chinese)

[4] Wang Jing, Tian Qiuli, Wang Xiaolu, "Miao Nan. Exploration of hybrid teaching method based on MOOC resources", Journal of Higher Education. 2017. (In Chinese)

[5] Chen Dan, Zhang Zhiqiang. "The research and practice of higher mathematics flipped classroom teaching mode under MOOC resources”, Science and Technology. 2016.12. (In Chinese)

[6] Yang Jinyun. "Research on the blended teaching mode of higher mathematics based on flipped classroom”. Journal of Higher Education. 2017.12. (In Chinese)

[7] Zhou Haiyu. "The application research of flipped classroom teaching mode based on micro-course in higher mathematics teaching", Journal of Liaoning Teachers College (Natural Science Edition). Vol. 19, 2017. (In Chinese) 